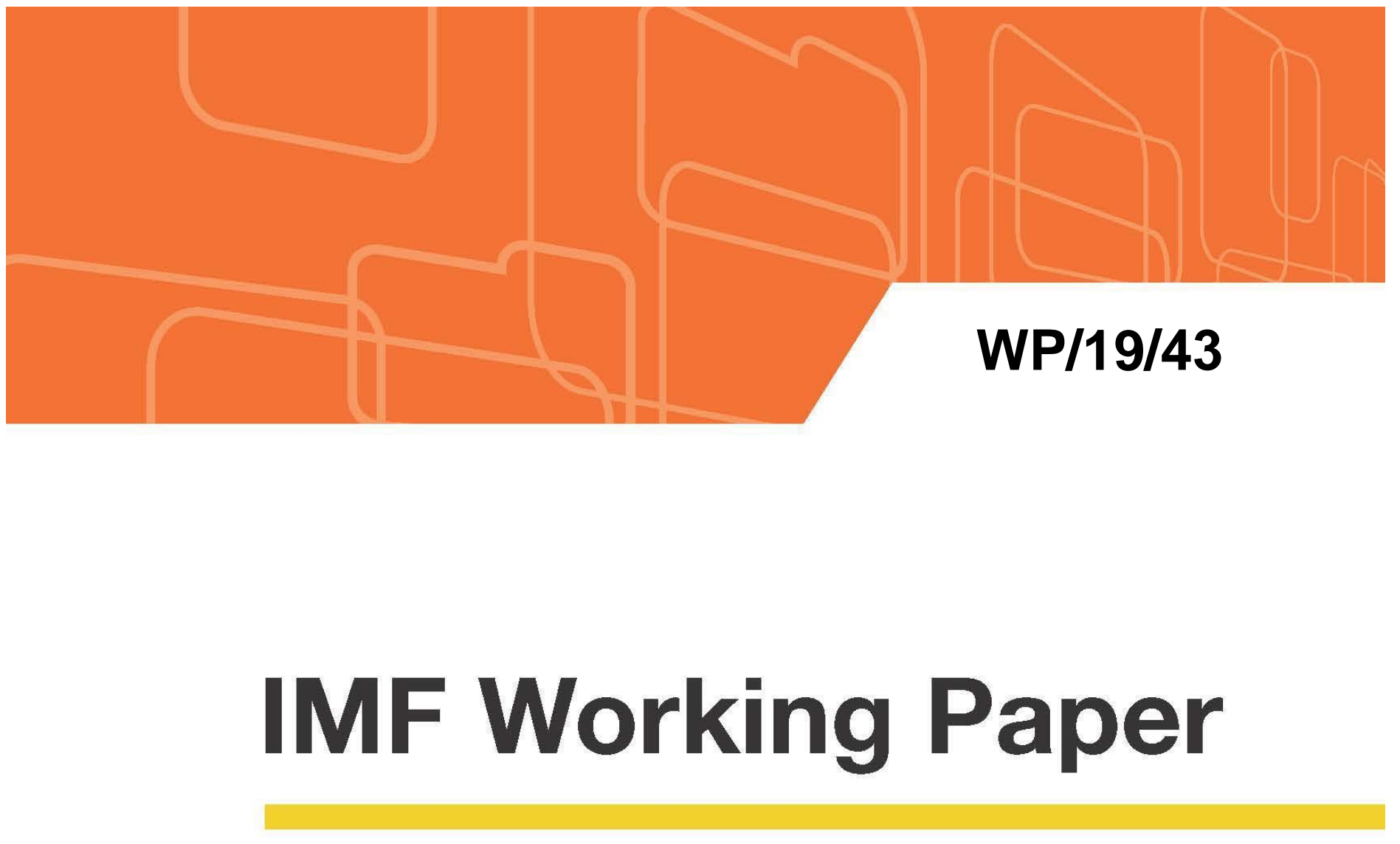

\title{
Sovereigns and Financial Intermediaries Spillovers
}

by Hamid Reza Tabarraei, Abdelaziz Rouabah, and Olivier Pierrard

IMF Working Papers describe research in progress by the author(s) and are published to elicit comments and to encourage debate. The views expressed in IMF Working Papers are those of the author(s) and do not necessarily represent the views of the IMF, its Executive Board, or IMF management. 


\title{
IMF Working Paper
}

Middle East and Central Asia Department

\section{Sovereigns and Financial Intermediaries Spillovers ${ }^{i}$}

\section{Prepared by Hamid Reza Tabarraei, Abdelaziz Rouabah, and Olivier Pierrard}

\author{
Authorized for distribution by Hossein Samiei
}

February 2019

\section{IMF Working Papers describe research in progress by the author(s) and are published to elicit comments and to encourage debate. The views expressed in IMF Working Papers are those of the author(s) and do not necessarily represent the views of the IMF, its Executive Board, or IMF management.}

\begin{abstract}
We examine the spillover effects between sovereigns and banks in a model with a heterogeneous banking system. An increase in sovereign's default risk affects financial intermediaries through two channels in this model. First, banks' funding costs might increase, inducing higher interest rates on loans and bonds and a cut back in these assets. Second, financial regulator's risk-weighted asset framework would assign higher weights to lower quality assets, implying a portfolio rebalancing and more deleveraging. While capital adequacy requirements weaken the impact of shocks emerging from the real economy, they amplify the effect of shocks on banks' balance sheets.

JEL Classification Numbers: H63, F34, G15

Keywords: Sovereign risk, Contagion, Interbank market

Author's E-Mail Address: htabarraei@imf.org, abdelaziz.rouabah@bcl.lu,$\underline{\text { olivier.Pierrard@ bcl.lu }}$

\footnotetext{
${ }^{\mathrm{i}}$ The authors thank Richard Portes, André Sapir, Philippe Martin, Harald Hau, Cédric Till, Romain Rancière, Hossein Samiei, Luc Riedwig, Daniel Hardy, and Olamide Harrison for their valuable comments. The views expressed in this paper are those of the authors and should not be reported as representing the views of the IMF, its Executive Board or its management, and the Banque Centrale du Luxembourg (BCL) or the Eurosystem.
} 


\section{Introduction}

Although the euro crisis had an unprecedented impact on countries in the euro area, the mechanism of propagation of sovereign risk to the financial sector and the real sector, in a general equilibrium framework, is fairly unexplored. Because European banks were the biggest holders of sovereign bonds in Europe, these banks were also the main conveyor of risks to other sectors of the economy and to other countries. ${ }^{1}$ For this reason, we add to the usual new-Keynesian framework a heterogeneous banking sector with risky government bonds. The goal is to find out the effects of sovereign default risk on the banking system and to analyze the role of banks in cross-sector propagation of shocks.

The literature on dynamic stochastic general equilibrium (DSGE) models with lending/borrowing relationships is relatively well-developed. Initial papers introduce frictions on the borrowing side of the economy, as in Bernanke and Gertler (1989), Carlstrom and Fuerst (1997), Kiyotaki and Moore (1997), Bernanke et al. (1999), Iacoviello (2005), Christiano et al. (2010) and Gertler and Karadi (2011). These papers examine the role of net worth and collateral to explain propagation and amplification of shocks. But lenders in these models are competitive and they accommodate the demand side of credit. More recently, some papers such as DeWalque et al. (2010) and Gerali et al. (2010) look at the lending side by developing a heterogeneous interbank market, suggesting that banks with low levels of capital or liquidity offer fewer loans when monetary conditions are tight or GDP growth is low. The results are important and empirically confirmed in Jimenez et al. (2012).

At one end, it is worth noting these models do not include a government sector with the possibility of default. On the other end, some recent papers such as Guerrieri et al. (2012) and Corsetti et al. (2013) have included sovereign debt probability of default (realized or not) into a new-Keynesian model, but have a simplified representation of the financial sector. The first paper shows that the international spillover of sovereign debt default may be sizeable. Meanwhile, the second paper shows that private sector beliefs of a weakening economy may become self-fulfilling when the monetary policy is constrained by the zero lower bound and cannot react to an increasing risk of sovereign default anymore.

Our paper combines the possibility of sovereign default within a framework that includes banking sector with frictions both on the borrowing and the lending sides. Many empirical research efforts, especially after the euro crisis, underline the spillover mechanism between sovereigns and banks. The results in Bruyckere et al. (2012) show that, given the home bias in the bond market, the sovereign/banks spillover effect is more important at the national level. Moreover, they find that the spillover effect depends on the capital adequacy ratio. Alter and Beyer (2013) build a contagion index and show important spillover effects from banks to sovereigns and vice-versa in periods of stress. These papers among many others illustrate the importance of including a well-defined and complex

\footnotetext{
${ }^{1}$ Among the resident holders of the euro area government debt in 2010, 80 percent were financial institutions, 4 percent was the European System of Central Banks and 16 percent were other residents (Hartwig Lojsch et al. (2011)).
} 
banking sector in the model if we would like to better understand the channels of transmission between sovereign risks and banks. In this regard, Dell'Ariccia et al. (2018) explain the various channels that give rise to a "sovereign-bank nexus".

For this purpose, we develop an interbank market with three types of banks: deposit, lending, and wholesale. Deposit banks are monopolistic and set the deposit interest rates with some adjustment costs. Lending banks are competitive and lend to entrepreneurs. Wholesale banks are at the center of the interbank market: they receive funds from deposit banks and provide liquidity to lending banks. Moreover, wholesale banks buy risky sovereign bonds and are subject to the minimum capital requirement rule. A Taylor rule governs the monetary policy. In this setting, the spread between interest rates on assets and liabilities of the wholesale bank is a positive function of the riskiness of assets and the bank leverage ratio position. On the real side of the economy, households consume, work, and transfer their saving to deposit banks. The production sector includes wholesale producers, capital producers and retailer whose prices are sticky à la Calvo. Finally there are entrepreneurs who offer entrepreneurial labor force and they buy capital from capital producers by combining their own net worth with borrowing from lending banks. Entrepreneurs rent this capital to wholesale producers and they resell the depreciated capital to the capital producer in the next period and buy new capital.

Entrepreneurs face heterogeneous productivity shocks. For those who receive a productivity shock lower than a certain threshold, the debt repayment is not possible, which leads to default. In this case they lose everything and the lending banks get the rest except a monitoring cost. At the equilibrium the external finance premium of entrepreneurs is a function of their net worth.

We assume that risk weights on bank assets are time-varying with the ex-ante default probability for each class of assets. This is consistent with the standardized approach of the Basel Committee on Banking Supervision and Internal Rating-Based approach in which risk-weights applied to banks and corporate exposures are time-varying. Therefore, deteriorating conditions in the market would lead to lower external or internal ratings associated to risk-weighted assets. On the other hand, it has become clear after the European debt crisis, that government bonds may be risky. Therefore, even in the Eurozone where a zero-weight is assigned to all EU government bonds, the debate has been opened as to whether these bonds should be subject to regulatory capital requirements in the future. On the whole, northern European countries argue that banks should hold some capital against sovereign debt holdings and southern European and emerging Asian countries oppose such a regulation ${ }^{1}$.

In this setting, the spreads between wholesale banks interest rates for interbank loans, sovereign bonds and the policy interest rate are functions of bank capital ratio such that higher bank leverage ratios imply higher spreads. On the other hand, under-capitalized banks face a regulatory cost.

\footnotetext{
${ }^{1}$ Although in December 2017 after two years of heated debates, the Basel committee published a discussion paper (Basel Committee Report on Banking Supervision (2017)) on the regulatory treatment of banks' sovereign debt holdings and concluded to maintain the status quo, acknowledging the lack of consensus among regulators, economists and practitioners on making any changes to the treatment of sovereign exposures. Nevertheless, the debate is ongoing and with the booming public debt in many advance economies, one has more reasons to believe that these regulatory changes would happen sooner or later.
} 
Sovereign default and interbank lending risks induce similar effects in the model, because these shocks directly affect wholesale banks' balance sheets. The difference, however, lies in the banks' portfolio adjustment and the propagation of shocks. In the case of a sovereign default risk shock, banks shift their portfolios toward the interbank lending. A similar but reverse mechanism occurs when a shock hits the interbank market.

If risk-weights associated to governmental bonds are non-zero, holding sovereign assets with increasing default probability makes banks under-capitalized and increases their leverage ratios. Consequently, in order to avoid the capital cost, banks should deleverage by offering less credit in the interbank market. At the same time, while the demand for sovereign bonds decreases, the risk premium on bonds goes up, putting further pressure on sovereign debt. Entrepreneurs net worth also decreases mainly because they cannot obtain as much credit as before leading to a downward path for investment and consequently output.

In this model, although the bank capital adequacy condition has an attenuating effect on the business cycle when a shock hits the real economy, it is reinforcing the effects of direct losses on banks' balance sheet. This is because banks must adjust their portfolios to respect the binding regulatory standards as soon as they can or otherwise, they have to pay a cost. In this case, banks have to cut down credit to the economy and the bond purchase. In addition, the time varying risk weight causes the capital adequacy ratio to bind sooner with increasing default probability. Moreover, deposit banks also attenuate the pass-through of monetary policy depending on their market power and interest rate adjustment costs. The model is flexible enough to analyze the impact of various shocks that originate from sovereign bond markets and financial intermediaries as well as to study monetary policy transmission in the presence of an interbank market.

Obviously, interactions between sovereign and banks are extremely complex, and our general equilibrium model does not certainly take all the channels into account. For instance, as explained in Brunnermeier and Pedersen (2009), a downward liquidity spiral can emerge because of the market liquidity conditions. Under these conditions, banks that are holding a significant amount of sovereign bond will not be able to sell them, which results in a further drop in the price of these assets. The fall in bonds prices puts banks and other financial intermediaries into more liquidity pressure. Also, a decrease in the price of bonds will decrease the amount of available collateral that banks can use to secure their wholesale funding. Banks use sovereign bonds as collateral in the repo market, covered bond issuance, in relation with central banks, and to back OTC derivative transactions among others. Higher sovereign risk not only decreases the value of collateral, but also can increase the haircut applied to sovereign securities. Kiyotaki and Moore (1997) and Kaminsky et al. (2003) are among the most well-known papers that explained this channel.

Sovereign downgrades also translate into lower credit ratings for domestic banks and other financial intermediaries. Candelon et al. (2011) analyzed European data between 2007 and 2010 and they found that a sovereign downgrade has spillover effects across countries and financial markets. In addi- 
tion, the financial system becomes deprived from implicit and explicit government guarantees. Brown and Dinc (2012) used the data for emerging economies in the 1990s and they showed that a government's support for distressed banks is affected by sovereign fiscal conditions and ratings. Another channel of spillover passes through the increase in investors risk aversion which in turn increases the risk premium on bank liabilities or reduces funding availability. There are other channels in work such as CDS repayment in a default event, risk of counterparty failure or low profitability because of fiscal consolidation. However, these channels are less relevant to our discussion. In turn, a weak banking system can affect sovereigns, mainly through the need for a bailout and also by reducing economic growth through amplifying shocks rather than absorbing them. Since the global crisis, it became more obvious that, the financial sector is not an indicator of economic downturn but an element that can suppress economic conditions even more or a sector where shocks may originate from.

In the next section, we go over the details of the model. Calibration, steady state values and functional form are discussed in section 3 where we also discuss the results. Finally we offer some concluding remarks.

\section{Model}

In this section, we develop a general equilibrium model with a financial accelerator mechanism à la Bernanke et al. (1999), including an interbank market with three types of banks. The model is flexible enough to include many shocks including those from sovereigns to the banking system and vice-versa.

The economy consists of a real sector, a financial sector, a central bank and a government. The real sector includes households, entrepreneurs and the production sector (wholesale producers, capital producers and retailers) similar to Bernanke et al. (1999) and Cohen-Cole and Martinez-Garcia (2011). The representative household consumes the final good sold by retailers and supplies labor to wholesale producers. The household also deposits her savings in deposit branks and is the ultimate beneficiary of both financial and non-financial firms. Wholesale producers choose capital and labor in competitive markets. Retailers buy goods from final goods producers and mark up prices via monopolistic competition with nominal price rigidities à la Christiano et al. (2005), Fernández-Villaverde and Rubio-Ramírez (2009) and Smets and Wouters (2007). Entrepreneurs use their net worth and borrow from lending banks to buy new capital from capital-producers and then lend it to wholesale producers. They also supply an entrepreneurial labor force to wholesale producers.

The financial sector includes deposit banks, lending banks and wholesale fund banks forming an interbank market. Deposit banks offer a one-period financial instrument to households, namely deposits. Lending banks also provide one-period loan contracts to entrepreneurs. The loan contract is subjected to a monitoring cost which incorporates an external finance premium and depends on the net worth of entrepreneurs. This is the financial accelerator. The deposit contract is also subject to a financial friction à la Gerali et al. (2010) due to a quadratic adjustment cost of deposit rates given 
the monopolistic power of deposit banks. Wholesale banks receive funds from deposit banks and the central bank, as a form of quantitative easing, and issue interbank loans to lending banks and buy government bonds. Wholesale banks are subject to a capital adequacy ratio (CAR) condition, which affects interest rates in the economy. In addition to following an inflation targeting policy by using the Taylor rule, the central bank conducts a quantitative easing program when necessary. The government issues one-period bonds which, for the sake of simplicity, are only accessible to wholesale banks. The following subsections describe the model in detail.

\subsection{Real Economy}

\subsubsection{Households}

Households maximize their life-time utility function which is driven from consumption and leisure:

$$
\max _{C_{s}, N_{s}, D_{s}} \mathbb{E}_{t}\left\{\sum_{s=t}^{\infty} \beta^{s-t} u\left(C_{s}, N_{s}\right)\right\}
$$

with the single period utility function as:

$$
u\left(C_{t}, N_{t}\right)=\frac{\left(C_{t}\right)^{1-\sigma}}{1-\sigma}-\eta \frac{N_{t}^{1+\phi}}{1+\phi}
$$

where $C_{t}$ is consumption and $N_{t}$ is hours worked. $\sigma$ and $\phi$ are parameters denoting household risk aversion and the inverse of the Frisch elasticity of labor supply respectively. The disutility for work is weighted by $\eta$. In each period, the household consumes $C$, deposit $D$ in banks and pay taxes $T$. Household budget constraint is

$$
C_{t}+D_{t}+T_{t} \leqslant \frac{R_{t-1}^{D} D_{t-1}}{\pi_{t}}+W_{t} N_{t}+\Pi_{t}^{R}+\Pi_{t}^{K}+\left(1-\alpha_{W}\right) \Pi_{t}^{B}
$$

$\Pi_{t}^{R}, \Pi_{t}^{K}$ and $\left(1-\alpha_{W}\right) \Pi_{t}^{B}$ are profits from good retailers, capital producers and dividend received from the banking sector respectively. Households supply labor $N$ to the wholesale producer and receive wages $W$ and the previous period deposits return $R_{t}^{D} \cdot \pi_{t}=P_{t} / P_{t-1}$ is the inflation rate. Maximising (1) subject to (2) yields the following first order conditions:

$$
\begin{aligned}
C_{t}^{-\sigma} & =\lambda_{t} \\
\eta N_{t}^{\phi} & =\lambda_{t} W_{t} \\
\lambda_{t} & =\beta \mathbb{E}_{t}\left[\frac{\lambda_{t+1}}{\pi_{t+1}}\right] R_{t}^{D}
\end{aligned}
$$




\subsubsection{Wholesale Producers}

The wholesale producers use entrepreneurial worker, $N_{t}^{E}$, household labor force, $N_{t}$ and capital $K_{t}$ to produce $Y_{t}^{W}$ of consumption goods using a Cobb-Douglas production technology:

$$
Y_{t}^{W}=e^{a_{t}} K_{t}^{1-\alpha-\rho} N_{t}^{\alpha}\left(N_{t}^{E}\right)^{\rho}
$$

where technology, $a_{t}$, follows an AR(1) process. Following Bernanke et al. (1999), we assume that the entrepreneurial share of labor is very small. Later, we suppose that entrepreneurs' labor supply is inelastic and we normalize it to one. Wholesale producers rent capital from entrepreneurs at real rate $r^{W}$ and they pay real salaries $W_{t}$ and $W_{t}^{E}$ to households and entrepreneurial labor forces. Wholesale producers seek to maximize:

$$
\Pi_{t}^{W}=P_{t}^{W} Y_{t}^{W}-r_{t}^{W} K_{t}-W_{t} N_{t}-W_{t}^{E} N_{t}^{E}
$$

where $P_{t}^{W}$ is the real marginal cost and every term is written in real terms. Wholesale producers are perfectly competitive and make zero profit. The first order conditions are:

$$
\begin{aligned}
R_{t}^{W} & =(1-\alpha-\rho) \frac{P_{t}^{W} Y_{t}^{W}}{K_{t}} \\
W_{t} & =\alpha \frac{P_{t}^{W} Y_{t}^{W}}{N_{t}} \\
W_{t}^{E} & =\rho \frac{P_{t}^{W} Y_{t}^{W}}{N_{t}^{E}}
\end{aligned}
$$

and therefore the marginal cost is:

$$
P_{t}^{W}=\frac{W_{t}^{\alpha}\left(W_{t}^{E}\right)^{\rho}\left(R_{t}^{W}\right)^{1-\alpha-\rho}}{\exp \left(a_{t}\right) \alpha^{\alpha} \rho^{\rho}(1-\alpha-\rho)^{1-\alpha-\rho}}
$$

\subsubsection{Capital producers}

The capital producing sector is a continuum of competitive agents. They use intermediate goods as investment $X_{t}$ and buyback depreciated capital $(1-\delta) K_{t}$ from entrepreneurs to produce new capital goods $K_{t+1}$. The capital accumulation dynamic is:

$$
\begin{aligned}
K_{t+1} & =(1-\delta) K_{t}+\Phi\left(\frac{X_{t}}{X_{t-1}}\right) X_{t} \\
\Phi\left(\frac{X_{t}}{X_{t-1}}\right) & =1-\frac{\chi}{2} \frac{\left(\frac{X_{t}}{X_{t-1}}-1\right)^{2}}{\frac{X_{t}}{X_{t-1}}}
\end{aligned}
$$


where $\Phi($.$) is the non-linear investment adjustment cost function following Christiano et al. (2010).$ Parameter $\chi$ measure the concavity of the technological constrains. The capital producers maximize:

$$
\max _{X_{s}} \mathbb{E}_{t} \sum_{s=t}^{\infty} M_{s, t}\left\{Q_{s} K_{s+1}-(1-\delta) Q_{s} K_{s}-X_{s}\right\}
$$

subject to the dynamic of capital where $M_{s, t}$ is the stochastic discount factor (SDF) and $Q_{t}$ is the price of capital for entrepreneurs or the Tobin's $Q$, which determines the relative cost of investment in units of consumption. In the production function of capital producers, we assumed that depreciated capital and new capital have the same price, $Q_{t}$ up to a first order estimation. Since households hold the capital producer firms, the SDF is computed as:

$$
M_{s, t}=\beta^{s-t} \frac{\lambda_{s}}{\lambda_{t}} \frac{1}{\pi_{s, t}}= \begin{cases}1 & s=t \\ \prod_{i=t}^{s-1} \frac{1}{R_{i}^{D}} & s>t\end{cases}
$$

where $\pi_{s, t}=P_{s} / P_{t}$ and $\lambda_{t}$ is the Lagrange multiplier in the household maximization program or its marginal utility of consumption. The first order condition for capital producer is therefore:

$$
Q_{t}\left[\frac{X_{t}}{X_{t-1}} \Phi_{t}^{\prime}\left(x_{t}\right)+\Phi\left(x_{t}\right)\right]=1+\frac{1}{R_{t}^{D}} \mathbb{E}_{t}\left[Q_{t+1} \Phi^{\prime}\left(x_{t+1}\right)\left(\frac{X_{t+1}}{X_{t}}\right)^{2}\right]
$$

where

$$
\Phi^{\prime}\left(x_{t}\right)=\chi \frac{\left(x_{t}-1\right)}{x_{t}}\left[\left(\frac{x_{t}-1}{2 x_{t}}\right)-x_{t}\right]
$$

with $x_{t}=X_{t} / X_{t-1}$. Equation (11) is the usual Tobin's Q equation which relates the price of capital to investment. It is also the equation for the supply of capital. The demand side for capital demand comes from the entrepreneurs maximization program.

The realized profit in each period is

$$
\Pi_{t}^{K}=Q_{t} K_{t+1}-(1-\delta) Q_{t} K_{t}-X_{t}
$$

In the steady-state the profit is zero, whereas during the transition process around the steady state, the adjustment cost cannot be set to its optimal level and therefore capital producers can realize a loss or profit. This is because at time $t, X_{t}$ is pre-determined.

\subsubsection{Retailers}

In order to introduce sticky prices, we assume a continuum of retailers indexed by $z$. The retailer buy $Y_{t}^{W}$ from wholesale producers and sell differentiated goods to households. The corresponding price 
index in the monopolistic competition framework is:

$$
P_{t}=\left[\int_{0}^{1} P_{t}(z)^{(1-\theta)} d z\right]^{\frac{1}{1-\theta}}
$$

The representative retail firm maximizes:

$$
\max _{Y_{t}(z)} Y_{t}-\int_{0}^{1} P_{t}(z) Y_{t}(z) d z
$$

subject to:

$$
Y_{t}=\left[\int_{0}^{1} Y_{t}(z)^{\frac{\theta-1}{\theta}} d z\right]^{\frac{\theta}{\theta-1}}
$$

This gives the usual CES demand function:

$$
Y_{t}(z)=\left(\frac{P_{t}(z)}{P_{t}}\right)^{-\theta} Y_{t}
$$

Retailers mark-up prices via monopolistic competition by using nominal rigidities as in Calvo (1983). Thus retailers can change their prices with a probability of $1-\alpha_{p}$ each period and the price remains constant with probability $\alpha_{p}$. Retailers who changed their prices at time $t$ choose the price $P_{t}^{*}(z)$ in order to maximize

$$
\max _{P_{t}^{*}(z)} \mathbb{E}_{t} \sum_{s=t}^{\infty} M_{s, t} \alpha_{p}^{s-t}\left\{\left(P_{t}^{*}(z)-P_{s}^{W}\right) Y_{s, t}^{*}(z)\right\}
$$

subject to

$$
Y_{s, t}^{*}(z)=\left(\frac{P_{t}^{*}(z)}{P_{s}}\right)^{-\theta} Y_{s}
$$

where $P_{t}^{*}(z)$ is the optimal price chosen at time $t$ and $Y_{s, t}^{*}(z)$ is the relative demand for variety $z$ at time $s$ given that its price is fixed at $P_{t}^{*}(z)$. The first order condition is:

$$
\mathbb{E}_{t} \sum_{s=t}^{\infty} M_{s, t} \alpha_{p}^{s-t}\left\{Y_{s, t}^{*}(z)\left(P_{t}^{*}(z)-\frac{\theta}{\theta-1} P_{s}^{W}\right)\right\}=0
$$

The good market clearing condition requires:

$$
\int_{0}^{1} Y_{t}(z) d z=Y_{t}^{W}
$$


The aggregate nominal profit is:

$$
\Pi_{t}^{R}=\int_{0}^{1}\left(P_{t}(z)-P_{t}^{W}\right) Y_{t}(z) d z
$$

which implies that:

$$
\Pi_{t}^{R}=Y_{t}-P_{t}^{W} Y_{t}^{W}
$$

\subsubsection{Entrepreneurs}

Entrepreneurs use their net worth and loans to buy new capitals:

$$
Q_{t} K_{t+1}=L_{t}+N W_{t}
$$

where $Q_{t}$ is the real price of purchasing new capital, $L_{t}$ is the loan borrowed from the retail lending banks and $N W_{t}$ is entrepreneurs' net worth. Entrepreneurs return is subject to aggregate and idiosyncratic risk. The ex-post return is $\omega R_{t}^{E}$ in which $\omega$ is an idiosyncratic risk and $R_{t}^{E}$ is the real aggregate return on capital. Entrepreneurs earn managerial wages in addition to the rent of capital and the value of depreciated capital. Assume $r_{t}^{W} K_{t}$ as the capital rent to the whole sale producers and $(1-\delta) Q_{t} K_{t}$ as the real resale value of the depreciated capital to the capital producers. The aggregate ex-post return on capital is therefore:

$$
R_{t}^{E}=\frac{r_{t}^{W}+(1-\delta) Q_{t}}{Q_{t-1}}
$$

If entrepreneurs receive a shock smaller than the cut-off shock $\bar{\omega}_{t+1}$, then they default. In the case of default, lending banks pay a monitoring cost and seize the gross capital return minus the auditing cost that is paid by entrepreneurs, i.e. $(1-\mu) \omega R_{t}^{E} Q_{t-1} K_{t}$, where $\mu$ is the coefficient for the monitoring cost. $\bar{\omega}_{t+1}$ is defined as:

$$
\bar{\omega}_{t+1} R_{t+1}^{E} Q_{t} K_{t+1}=R_{t}^{L} L_{t}
$$

where $R_{t}^{L}$ is real the interest rate on the loan obtained from lending banks. Obviously, for $\omega \geqslant \bar{\omega}_{t+1}$, entrepreneurs pay $R_{t}^{L} L_{t}$ to lending banks and keep the difference, $\omega R_{t+1}^{E} Q_{t} K_{t+1}-R_{t}^{L} L_{t}$. Therefore, their expected profit next period is:

$$
V_{t}=\mathbb{E}_{t} \Pi_{t+1}^{E}=\mathbb{E}_{t}\left[\int_{\bar{\omega}_{t+1}}^{\infty} \omega R_{t+1}^{E} Q_{t} K_{t+1} d F(\omega)-\left(1-F\left(\bar{\omega}_{t+1}\right)\right) R_{t}^{L} L_{t}\right]
$$

By replacing $R_{t}^{L} L_{t}$ from equation (19), profit can be simplified as follow:

$$
V_{t}=\mathbb{E}_{t}\left[\left(\int_{\bar{\omega}_{t+1}}^{\infty} \omega d F(\omega)-\bar{\omega}_{t+1} \int_{\bar{\omega}_{t+1}}^{\infty} d F(\omega)\right) R_{t+1}^{E} Q_{t} K_{t+1}\right]
$$




\subsection{Banking Sector:}

\subsubsection{Lending banks}

The lending banks obtain a wholesale loan $L_{t}$ at $R_{t}^{I}$. The banks are in perfect competition and the zero profit condition implies that what they pay to wholesale banks should be equal to their earning from lending to entrepreneurs:

$$
\int_{\bar{\omega}_{t+1}}^{\infty} R_{t}^{L} L_{t} d F(\omega)+(1-\mu) \int_{0}^{\bar{\omega}_{t+1}} \omega R_{t+1}^{E} Q_{t} K_{t+1} d F(\omega)=R_{t}^{I} L_{t}
$$

Let's define:

$$
\begin{aligned}
& \Gamma_{t}\left(\bar{\omega}_{t+1}\right)=\bar{\omega}_{t+1} \int_{\bar{\omega}_{t+1}}^{\infty} d F(\omega)+\int_{0}^{\bar{\omega}_{t+1}} \omega d F(\omega) \\
& G_{t}\left(\bar{\omega}_{t+1}\right)=\int_{0}^{\bar{\omega}_{t+1}} \omega d F(\omega)
\end{aligned}
$$

then the profit of lending banks can be rewritten as:

$$
\left[\Gamma\left(\bar{\omega}_{t+1}\right)-\mu G\left(\bar{\omega}_{t+1}\right)\right] \varrho_{t} \frac{R_{t+1}^{E}}{R_{t}^{I}}=\varrho_{t}-1
$$

where $\varrho_{t}=Q_{t} K_{t+1} / N W_{t}$ is the entrepreneurs' leverage ratio. Entrepreneurs choose $\varrho_{t}$ and $\bar{\omega}_{t+1}$ (or equivalently $R_{t}^{L}$ ) in order to maximize their profit, equation (20), subject to the zero net profit of lending banks, equation (24). As a result:

$$
\frac{R_{t+1}^{E}}{R_{t}^{I}}=\Lambda\left(\bar{\omega}_{t+1}\right) \quad \text { with } \quad \Lambda^{\prime}(.)>0
$$

The detail of calculation can be found in the appendix. As shown in Bernanke et al. (1999), $\Lambda\left(\bar{\omega}_{t+1}\right)$ guarantee a one-to-one mapping between the optimal cutoff $\bar{\omega}_{t+1}$ and the premium on external fund. Combining equation (25) with banks' zero net profit condition (21), gives a relationship between entrepreneur's leverage level, $\varrho_{t}$, and external fund premium, $R_{t+1}^{E} / R_{t}^{I}$. This relationship guarantees an interior solution for $\bar{\omega}_{t+1}$ and thus it can be summarized as follow:

$$
Q_{t} K_{t+1}=\Psi\left(\frac{R_{t+1}^{E}}{R_{t}^{I}}\right) N W_{t}
$$

where $\Psi(1)=1$ and $\Psi^{\prime}()>$.0 . This relationship indicates entrepreneurs demand for new capital.

Let $V_{t}$ be entrepreneurial accumulated wealth from operating firms. The dynamic of the net worth of entrepreneurs is:

$$
N W_{t}=\gamma V_{t}+W_{t}^{E}
$$


where $\gamma V_{t}$ is the equity (their profit) held by entrepreneurs at $t-1$ and $C_{t}^{E}=(1-\gamma) V_{t}$ is consumed by them. The equity is:

$$
V_{t}=R_{t}^{E} Q_{t-1} K_{t}-\left(1-d_{t-1}^{L}\right) R_{t-1}^{I} L_{t-1}-\mu \int_{0}^{\bar{\omega}_{t}} \omega R_{t}^{E} Q_{t-1} K_{t} d F(\omega)
$$

where $d_{t}^{L}$ is the exogenous ex-ante default probability of lending banks. Combining this with equations (8) and (27) gives:

$$
N W_{t}=\gamma\left(R_{t}^{E} Q_{t-1} K_{t}-\left(1-d_{t-1}^{L}\right) R_{t-1}^{I} L_{t-1}-\mu \int_{0}^{\bar{\omega}_{t}} \omega R_{t}^{E} Q_{t-1} K_{t} d F(\omega)\right)+W_{t}^{E}
$$

This can be reorganized to better see the external finance premium.

$$
\begin{aligned}
N W_{t}= & \gamma\left\{R_{t}^{E} Q_{t-1} K_{t}\right. \\
& \left.-\left(\left(1-d_{t-1}^{L}\right) R_{t-1}^{I}+\frac{\mu \int_{0}^{\bar{\omega}_{t}} \omega R_{t}^{E} Q_{t-1} K_{t} d F(\omega)}{Q_{t-1} K_{t}-N W_{t-1}}\right)\left(Q_{t-1} K_{t}-N W_{t-1}\right)\right\}+W_{t}^{E}
\end{aligned}
$$

where

$$
\frac{\mu \int_{0}^{\bar{\omega}_{t}} \omega R_{t}^{E} Q_{t-1} K_{t} d F(\omega)}{Q_{t-1} K_{t}-N W_{t}}
$$

is the external finance premium. We also assume that lending banks restrict the leverage ratio of entrepreneurs to a fraction $e$ of their capital holding:

$$
L_{t}=\rho^{l} L_{t-1}+\left(1-\rho^{l}\right) e K_{t}
$$

\subsubsection{Deposit banks:}

We chose competitive lending banks because we wanted to compare a usual financial accelerator with our model, which includes an interbank market. However, deposit banks are monopolistic and in line with Gerali et al. (2010) and Dib (2010) they are price setters. Therefore, depositors ask for a bundle of deposit products, such that:

$$
D_{j, t}=\left(\frac{R_{j, t}^{D}}{R_{t}^{D}}\right)^{\varepsilon} D_{t}
$$

where $R_{j, t}^{D}$ is the offered interest rate by each bank $j$. By setting the interest rates, deposit banks face a quadratic adjustment cost $\grave{a}$ la Rotemberg. These banks then transfer the collected deposits to the 
wholesale bank at the rate $R_{t}^{I B}$. They maximize:

$$
\max _{R_{j, s}^{D}} \mathbb{E}_{t} \sum_{s=t}^{\infty} M^{s-t}\left\{R_{t}^{I B} D_{j, s}-R_{j, s}^{D} D_{j, s}-\frac{\kappa_{D}}{2}\left(\frac{R_{j, s}^{D}}{R_{j, s-1}^{D}}-1\right)^{2} D_{s}\right\}
$$

Symmetric equilibrium implies $R_{j, t}^{D}=R_{t}^{D}$ for all $j \in(0,1)$ and thus the first order condition simplifies to:

$$
\frac{1+\varepsilon}{\varepsilon} R_{t}^{D}=R_{t}^{I B}-\frac{\kappa_{D}}{\epsilon}\left(\frac{R_{t}^{D}}{R_{t-1}^{D}}-1\right) \frac{R_{t}^{D}}{R_{t-1}^{D}}+\frac{M \kappa_{D}}{\epsilon}\left(\frac{R_{t+1}^{D}}{R_{t}^{D}}-1\right) \frac{R_{t+1}^{D}}{R_{t}^{D}}
$$

This is the optimal condition for deposit interest rate which is a mark-down with respect to the interbank rate. The interest rate spread is simply the markup between bank costs and what banks charge for their interbank lending. The spread is time varying and it increases in the net marginal cost of adjustment across time. This is another financial friction in the model which facilitates consumption smoothing by damping big surprises in deposit rates.

\subsubsection{Wholesale Banks}

Contrary to deposit banks, wholesale banks are quantity takers in competitive wholesale financial markets (see Rousseas (1985)) and therefore they are competitive. These banks use their bank capital, $K^{W B}$, receive funds from deposit banks, and they also use the central bank liquidity facilities. All sources of funds are perfect substitutes. The wholesale banks buy government bonds, pay interest on bank funds received from deposit banks, and give loans to lending banks. Wholesale banks assets are government bonds and loans to lending banks. The regulatory authority imposes a capital requirement on them such that wholesale banks have to maintain a capital-to-asset ratio $\lambda_{W}{ }^{1}$. Banks should maintain an extra capital, $S_{t}$ such that:

$$
K_{t}^{W B}=S_{t}+\lambda_{W}\left(\delta_{t}^{b} B_{t}+\delta_{t}^{l} L_{t}\right)
$$

Following Kollmann et al. (2011), we assume that wholesale banks pay a cost $\Omega\left(S_{t}\right)$ if the capitalto-asset level is less than $\lambda_{W}$, i.e, $S_{t}<0$ with $\Omega\left(S_{t}\right)>0$ for $S_{t}<0$ and $\Omega(0)=0$, where $\Omega$ is a convex function. According to this assumption, bank capital plays an important role in determining the availability of credit to lending banks, $L_{t}$, and government bonds, $B_{t}$. It also impacts the price of credit. Therefore, wholesale banks play the main role in transferring shocks from financial sectors to the real sector and vice versa. In a deteriorating macroeconomics environment, banks' profits and

\footnotetext{
${ }^{1}$ In reality, the capital requirement condition is imposed on all type of banks and not only on wholesale banks. Nevertheless, the model abstracts of the capital requirement conditions on deposit and lending banks by assuming that they are in fact branches of the wholesale banks (see equation (38))
} 
capital get hit and they may respond by reducing the amount of available credit to the private sector which in turn might amplify shocks in the real economy and leads to a further contraction.

In equation (34), $\delta_{t}^{b}$ and $\delta_{t}^{l}$ are the risk weighted asset coefficients. Under the standardized approach of the Basel Committee on Banking Supervision, sovereign exposures are risk-weighted according to their external ratings on an increasing scale. However, In most regulatory frameworks, sovereign exposures are treated more favorably compared to other asset classes. In many cases, riskweights assigned to domestic sovereign bond holding in domestic currency is zero. Also under the internal-ratings-based (IRB) approach, banks can use their own models to estimate default probabilities and loss-given-default, using a granular rating scale to assess the credit of individual sovereigns. In our model, we assume that these weights are risk-sensitive meaning that if assets are downgraded, i.e. default probabilities increase, the associated weights also increase:

$$
\begin{aligned}
\delta_{t}^{b} & =\overline{\delta^{b}}\left(1+d_{t}^{B}\right)^{\eta_{b}} \\
\delta_{t}^{l} & =\overline{\delta^{l}}\left(1+d_{t}^{L}\right)^{\eta_{l}}
\end{aligned}
$$

where we denote by $d_{t}^{L}$ and $d_{t}^{B}$, the external default probabilities in $t+1$ for lending banks and government bonds. Thus, wholesale banks' balance sheet identity follows:

$$
D_{t}+K_{t}^{W B}=B_{t}+L_{t}
$$

We assume that bank capital is accumulated as follows:

$$
\begin{aligned}
K_{t}^{W} & =\left(1-\rho^{W}\right) K_{t-1}^{W}+\alpha^{W} \Pi_{t}^{B} \\
\Pi_{t}^{B} & =\Pi_{t}^{S}+\Pi_{t}^{W B}
\end{aligned}
$$

in which $\Pi_{t-1}^{S}$ and $\Pi_{t-1}^{W B}$ are profits of deposit banks and wholesale banks. $1-\alpha^{W}$ can be interpreted as wholesale bank dividend policy and $\rho^{W}$ stands for banks' operational and managerial costs. Wholesale banks are hold by households and they choose $B_{t}$ and $L_{t}$ to maximize the discounted sum of cash flows subject to regulatory constrain and balance sheet identity:

$$
\max _{B_{t}, L_{t}, D_{t}, S_{t}} \mathbb{E}_{t} \sum_{s=t}^{\infty}\left[M_{s, t} \Pi_{s}^{W B}\right]
$$

subject to constraint (30), (34) and (37). The cash flow in each period is:

$$
\Pi_{t}^{W B}=\left(1-d_{t}^{L}\right) R_{t-1}^{I} L_{t-1}-L_{t}+\frac{\left(1-d_{t}^{B}\right) R_{t-1}^{B} B_{t-1}}{\pi_{t}}-B_{t}-\frac{R_{t}^{I B} D_{t-1}}{\pi_{t}}+D_{t}-\Omega\left(S_{t}\right)
$$


Replacing the balance sheet identity, equation (37), the cash flow simplifies to:

$$
\Pi_{t}^{W B}=\left(1-d_{t}^{L}\right) R_{t-1}^{I} L_{t-1}+\frac{\left(1-d_{t}^{B}\right) R_{t-1}^{B} B_{t-1}}{\pi_{t}}-\frac{R_{t-1}^{I B} D_{t-1}}{\pi_{t}}-K_{t}^{W B}-\Omega\left(S_{t}\right)
$$

The first order conditions are:

$$
\begin{aligned}
M_{t+1, t} \mathbb{E}_{t}\left(\left(1-d_{t}^{L}\right) R_{t}^{I}-\frac{R_{t}^{I B}}{\pi_{t+1}}+\rho^{l} \zeta_{t+1}\right) & =\zeta_{t}-\lambda_{W} \delta^{l} \Omega^{\prime}\left(S_{t}\right) \\
M_{t+1, t} \mathbb{E}_{t}\left(\frac{\left(1-d_{t}^{B}\right) R_{t}^{B}-R_{t}^{I B}}{\pi_{t+1}}\right) & =-\lambda_{W} \delta^{b} \Omega^{\prime}\left(S_{t}\right)
\end{aligned}
$$

where $\zeta_{t}$ is the associated Lagrange multiplier to the loan constraint, equation (30). To simplify, we assume that the interbank rate is equal to the central bank policy rate, i.e. $R_{t}^{I B}=R_{t}$, so wholesale banks are indifferent between funds from the central bank and the interbank market. In the case that wholesale banks are under-capitalized, i.e. $S_{t}<0$, they have to pay a cost. The under-capitalization implies a higher interest rate spreads between rates applied to sovereign debt and loans to lending banks and the policy rate (because $\Omega^{\prime}\left(S_{t}\right)<0$ ). Because of a convex functional form for $\Omega($.$) , banks'$ higher leverage ratio implies higher spread both on bond assets and loans to lending banks.

\subsection{Central bank, government and Market Clearing}

\subsubsection{Central bank}

The central bank follows a Taylor rule such as:

$$
\log \frac{R_{t}}{R}=\rho_{\pi} \log \frac{\pi_{t}}{\pi}+\rho_{y} \log \frac{Y_{t}}{Y}+\varepsilon_{t}^{R}
$$

where $R, \pi$ and $Y$ are the steady state values for the policy rate, inflation and the output respectively.

\subsubsection{Government:}

The government buys a fraction $G_{t}$ of final good, for public consumption and it finances this operation by collecting taxes and issuing public bonds.

$$
G_{t}+\frac{R_{t-1}^{B}\left(1-\delta_{t}^{b}\right) B_{t-1}}{\pi_{t}}=B_{t}+T_{t}
$$

We assume that government tax, $T_{t}$ follows an $\mathrm{AR}(1)$ process:

$$
T_{t}=\left(1-\rho^{T}\right) \tau Y_{t}+\rho^{T} T_{t-1}
$$


where $\tau$ is the tax rate. Following Guerrieri et al. (2012), we assume that government ability in issuing bonds is limited and it is tied to the government debt repayment history. Thus we assume a debt limit such as:

$$
B_{t}=\left(\left(1-d_{t}^{B}\right) B_{t-1}\right)^{\rho_{b}} \bar{B}^{\left(1-\rho_{b}\right)}
$$

where $\bar{B}$ is the debt steady state level. We choose this parameter as 60 percent of GDP, which is the maximum level of debt fixed by many fiscal rules in different countries (also in the Maastricht treaty). $\rho_{b}$ is a parameter which controls the government debt issuance dependence to its previous debt funding.

\subsubsection{Market clearing for goods}

Final good (sold by retailers) should be equal to the sum of all consumption goods plus all adjustment costs.

$$
\begin{aligned}
Y_{t}=C_{t}+C_{t}^{E}+G_{t} & +X_{t} \\
& +\mu \int_{0}^{\bar{\omega}_{t}} \omega d F(\omega) R_{t}^{E} Q_{t-1} K_{t}+\frac{\kappa_{D}}{2}\left(\frac{R_{t}^{D}}{R_{t-1}^{D}}-1\right)^{2} D_{t} \\
& +\Omega\left(S_{t}\right)+K_{t}^{\mathrm{WB}}-\left(1-\rho^{W}\right) K_{t-1}^{\mathrm{WB}}
\end{aligned}
$$

\section{Results}

Using the quarterly data, the model's parameters are calibrated for the euro zone. The discount factor is set to 0.99 for households which implies an annual deposit rate of 0.041 percent. The Frisch elasticity of labor is calibrated as 0.1 , implying a high elasticity. The elasticity of consumption for households is set to 0.5. $\eta$ is calibrated such that in the steady states $C / Y=0.6076$. Therefore total consumption -of households and entrepreneurs- to GDP is equal to 0.7298. The fraction of total labor employment in the production function is 0.7 and the share of entrepreneurial labor is set to 0.01 .

The quarterly rate of capital depreciation is 0.025 , which implies almost a 10 percent annual rate. The parameter for capital producer adjustment cost is equal to 20. Calvo parameter $\alpha_{p}$ is assumed to be 0.75 , which corresponds to one change in price per year. We follow Bernanke et al. (1999) in calibrating the monopolistic power of retailers by setting it equal to 6 . So the markup is 1.2 at the steady state. Also at the steady-state, the leverage ratio of entrepreneurs is equal to 2 and the external finance premium is equal to 114 b.p. quarterly.

The deposit banks' monopolistic power is set to 50 and the parameter for the interest rate adjustment is calibrated to 2.4 to match the average historical $R_{t}^{D}$. The minimum capital to risk-weighted assets is set to 0.08 according to Basel II and III accords. We assume that wholesale bank holds 
"A" rated government bonds and the lending banks are rated "A". According to risk-weighted asset schema in Basel II and III, this implies $\bar{\delta}^{b}$ to be equal to 0.20 and $\bar{\delta}^{l}$ is therefore set to 0.50 .

We use the average implied default probability one quarter before the downgrade to calibrate $\bar{\eta}^{b}$. Italy had A rated bonds before January 2012 and the average default probability was around 6.5 percent. In January its sovereign bonds were downgraded to $\mathrm{BBB}^{+}$, with an average default probability of 8.5 percent. The risk-weight for "A" rated sovereign bonds is 0.2 and it is equal to 0.5 for $\mathrm{BBB}^{+}$. This gives us the value of $\bar{\eta}^{b}$ equal to 46.27 according to Basel II and III. Risk-weight for " $\mathrm{A}$ " rated banks is 50 percent and for $\mathrm{BBB}^{+}$is 100 percent. Therefore we use again the average implied probability of default for banks and we use the difference to calculate $\bar{\eta}^{l}$. The value for this parameter is equal to 17.5 .

Taylor rule parameters $\rho_{\pi}$ and $\rho_{Y}$ are set to 1.5 and 0.05 . Lubik (2003) shows that $\rho_{\pi}$ should be bigger than 1 for determinacy reasons. The autocorrelation for government spending process is 0.8 , following Dib (2010).

Other parameters are calibrated to match the steady state values in the data. Investment to output is equal to 0.0524 and public spending to GDP is 0.1728 . Table 1 and 2 summarize the calibrated parameters and steady state values of variables.

\subsection{Monetary shock}

First, we analyze the transmission of monetary shock in the economy. We compare our results with the well-documented results in other papers such as Christiano et al. (2010) and Smets and Wouters (2003). Once, the benchmark model reproduced the same results for this shock, we could look into the focus of this paper which is the cross-section spillover between sovereign and the banking system.

Three models are compared to the full model in the supply side of the economy; First, we analyze the impact of capital requirement by varying the coefficient of the cost function $\Omega\left(S_{t}\right)=$ $\alpha_{S}\left(\exp \left(-\kappa_{S} S_{t}\right)-1\right)$. Second, we are interested in comparing Basel I with Basel II and III by eliminating the risk weighted asset framework from the model. And third, we assume no Rotemberg cost for the deposit interest rate adjustment. We compare these three models with the full model. All charts except those for the interest rates report percentage deviations from the steady state. The interest rate graphs are shown as absolute deviation from steady state in percentage points.

Figures 3 and 4 depict the response to an unanticipated 25 basis point decline in the policy interest rate on an annual basis. As expected output and consumption increase as well as investment and capital stock increase. Higher capital demands imply a higher demand for loans. Entrepreneurs' net worth rises as loan rates decline and their default rate declines, which leads to a reduced external premium. This is how the financial accelerator operates in this economy.

Figure 3 compares the complete model and the model without the Rotemberg adjustment cost depicted in bold black graphs and dashed blue lines. Due to the adjustment cost, the deposit rate in 
the full model does not follow the policy interest rate. As a result, deposit increases at the expense of households' consumption which increases only moderatly in the full model. On the contrary, in the model without Rotemberg cost, the deposit rate follows the policy rate by a mark-down. In this case, a decrease in the deposit rate, initially lowers the deposit volume, but this effect is later offset by an increase in the household income, leading to accumulation of deposit.

With more valueables loan assets on the balance sheet, wholesale banks' leverage ratios momentarily fall, i.e. banks become initially over-capitalized. However, as the demand for loans builds up, leverage ratios rises again. In the absence of the Rotemberg cost, the financial accelerator reinforces the shock more aggressively, meaning that investment and output rise faster. In this sense, financial variables show higher sensitivities to the Rotemberg cost. In a nutshell, with abstracting from deposit rate adjustment cost, banks choose holding higher capital levels, because deposits drop more. This forces banks to inquire more capital to not only compensate for the new demand for loans, but also to make up for the decline in deposit funding. Finally, as the bond supply dynamic is supposed to be exogenous, the interest rate on bonds, $R_{t}^{B}$, closely follows the policy interest rate.

In figure 4, we compare the full model again with a model in which under-capitalization cost for wholesale banks is removed. Banks' capital holding requirements, in general, show little impact in the case of a monetary expansion policy. Wholesale banks with better capital positions lower interest rates spread (between interest rates on bonds and loans and policy interest rates) and this causes a better transmission of the monetary policy. When a negative monetary shock hits the economy, wholesale banks realize a small profit due to holding of some extra capital. Moreover, the external premium is lower in the case of non-zero capital cost, initially, because wholesale banks' excess-capital holding makes interest rates on loans cheaper - according to the equation (41). Other than that, the impact of bank capital cost is negligible on other variables. The models for Basel I and for Basel II \& III have the same impulse response functions, because the risk weights are not changing following a monetary shock.

\subsection{Sovereign risk shock}

The main purpose of the exercise is to examine the bank-sovereign nexus and channels through which sovereign risks transmitt to banks and the real economy. Assuming the default risk on governmental bonds as an exogenous shock, figures 5 through 7 analyse the response of macro-fiancial variables to a 2 percent increase in the sovereign default risk. For this purpose, we feed into the model a series of unexpected shocks which lasts around 2 years in the economy. However, the impact on the real economy lasts for longer periods, due to the sluggish adjustment mechanisms for investment, deposit, and bonds in the model.

Because of higher sovereign default risk, the interest rate on bonds shoots up and the demand for bonds falls down to close to 3.5 percent of its steady state level. The higher default probability 
implies losses on banks' balance sheets with two simultaneous effects. First, their funding cost rises as banks' assets value diminishes and their leverage ratios upswing, compelling them to pay an extra cost. Second, the weight associated to bonds in the risk weighted asset framework increases with the asset rating. Both factors oblige banks to pay an extra cost for managing their capital positions, further reducing their profitability and deteriorating their capital positions. Besides, according to equations (41) and (42), interest rate spreads widen, making the impact on the real economy harsher. The outcome is lower supply for loans and lower demand for bonds, leading to asset prices drop and higher interest rates. This process shows how higher sovereign risk through banks' balance sheets can be reinforced and transmitted to the economy (although in our model, the risk of default remains exogenous and is not affected by the interest rate rise). Following an increase of 2 percent in sovereign default risk, the GDP can shrink by more than 3 percent and the interest rate on bonds rises by 5 percent. Because of the fall in asset values, banks leverage ratio grows higher to around 30 percent of its steady state.

In addition to the drop in wholesale banks' profits, retailers and capital producers also realize a contraction in their profits which eventually leads to labor drop. This leaves households with lower income levels. The monetary policy reacts with a contraction in the policy rate. The desposit rates follows and this allows households to smooth their consumption by dissaving.

We evaluate the effect of the financial accelerator in figure 5. Here, the financial accelerator mechanism is removed from the model by fixing the external premium equal to its steady state. Although the bank capital and the leverage ratio responses are initially the same in both models, the model with the financial accelerator (solid black line) shows higher persistence. The financial accelerator essentially works on the monetary policy channel and changes the responses on various interest rates, inflation and investment.

The blue dashed line in figure 6 demonstrates the model with no bank capital cost for a higher default risk shock. In the absence of bank capital cost, i.e. $\alpha_{S}=0$, wholesale banks' profit remains higher, banks are better capitalized and the leverage ratio remains lower when the risk of default rises. Equation (42) implies that the spread between the interest rates on bonds and loans and the policy interest rate to be higher for the full model. However, $R_{t}^{E}$ does not increase enough to compensate the rise in $R_{t}^{I}$. Consequently, the external premium, $R_{t}^{E} / R_{t}^{I}$ is lower in the full model.

The capital adequacy condition amplifies the shock arising in the sovereign bond market. Following the shock, wholesale banks try to reshuffle their portfolio to recover their capital position and leverage ratios by reducingcutting balance sheet channel. ${ }^{1}$. This is the balance sheet channel. On the other hand, interest rates on bonds and loans go up. This is the interest rate channel. The monetary authority reacts more in the full model, because the economy plunges deeper in a recession. For this

\footnotetext{
${ }^{1}$ Another channel is the collateral constraint channel. In the case of a shock to banks' balance sheet, the central bank can not provide banks with the same volume of liquidity, because these facilities are collateralized by high quality assets which are usually government bonds. This channel does not exist in this exercise.
} 
reason, the monetary policy reaction compensates the hike in market interest rates, to some extent.

Because of the interest rate and the external premium channels, investment declines. Consumption initially increases, because households save less due to lower deposit rates. However, with lower economic activities and recovering deposit, consumption declines. Therefore, the output shrinks due to drop in investment, public spending and private consumption in later stages.

We also compared the full model with a model without the Rotemberg cost. The two models demonstrate the same behavior for a default risk shock, except mainly for the deposit rate. Naturally, the response of this variable is more pronounced when there is no adjustment cost for the deposit rate.

The impulse response functions show the role of each component of the model for each shock. Some elements are more important for one particular shock than the other, such as the Rotemberg adjustment cost for the monetary shock and the capital requirement costs for the sovereign risk. This model enables us to further analyze the role of monetary and macro-prudential policies in attenuating the negative spillovers of a potential sovereign default shock.

\section{Conclusion}

This paper suggests a heterogeneous banking sector in a New-Keynesian framework in order to investigate the sovereigns-banks nexus. The banking sector includes two retail sectors for loans and deposits and a wholesale funding sector. Lending banks channel loans from wholesale banks to the real economy and the deposit banks channel households' deposit to wholesale banks.

The wholesale banks are subjected to a capital adequacy ratio and we use Basel II and III rules for risk weighting assets framework. The wholesale banks balance sheet is the key factor in amplifing the shock arising from higher sovereign risks. Due to a direct loss on the balance sheet due to asset valuation, banks become highly leveraged, requiring them to readjust their portfolios and a further cut in loans and bond purchase. Because of the capital position of the banks, interest rates on bonds and loans rise, which dampens investment and output.

In addition to their balance sheets, banks are affected through capital adequacy ratios as the requirements would bind sooner with higher probablities of default. In addition the model incorporates, varying risk weights with the credit risks for each class of assets. Although we have not included other mechanisms such as the state guarantee and interdependence of credit ratings, the model still captures the positive feedback mechanism between sovereigns and banks.

The bank balance sheet plays an important role in amplifying shocks to other sectors of the econ-

omy. The capital adequacy condition attenuates the effect of technology and monetary shocks, but reinforces the impact of shocks, such as higher sovereign default and interbank risks, with a direct effect on banks' balance sheets. 


\section{References}

Alter, A. and Beyer, A. (2013). The dynamic of spillover effect during the european sovereign debt turmoil. Working Paper Research 1558, The European Central Bank.

Angeloni, I. and Faia, E. (2009). A tale of two policies: Prudential regulation and monetary policy with fragile banks. Kiel Working Papers 1569, Kiel Institute for the World Economy.

Basel Committee Report on Banking Supervision (2017). The regulatory treatment of sovereign exposures.

Bernanke, B. and Gertler, M. (1989). Agency costs, net worth, and business fluctuations. American Economic Review, 79(1):14-31.

Bernanke, B. S., Gertler, M., and Gilchrist, S. (1999). The financial accelerator in a quantitative business cycle framework. In Taylor, J. B. and Woodford, M., editors, Handbook of Macroeconomics, volume 1 of Handbook of Macroeconomics, chapter 21, pages 1341-1393. Elsevier.

Brown, C. O. and Dinc, I. S. (2012). Too many to fail? evidence of regulatory forbearance when the banking sector is weak. Review of Financial Studies, 24(4):1378-1405.

Brunnermeier, M. K. and Pedersen, L. H. (2009). Market liquidity and funding liquidity. Review of Financial Studies, 22(6):2201-2238.

Bruyckere, V. D., Gerhardt, M., Schepens, G., and Vennet, R. V. (2012). Bank/sovereign risk spillovers in the european debt crisis. Working Paper Research 232, National Bank of Belgium.

Calvo, G. A. (1983). Staggered prices in a utility-maximizing framework. Journal of Monetary Economics, 12(3):383-398.

Candelon, B., Sy, A. N. R., and Arezki, R. (2011). Sovereign rating news and financial markets spillovers: Evidence from the european debt crisis. IMF Working Papers 11/68, International Monetary Fund.

Carlstrom, C. T. and Fuerst, T. S. (1997). Agency costs, net worth, and business fluctuations: A computable general equilibrium analysis. American Economic Review, 87(5):893-910.

Christensen, I. and Dib, A. (2008). The financial accelerator in an estimated new keynesian model. Review of Economic Dynamics, 11(1):155-178.

Christiano, L., Rostagno, M., and Motto, R. (2010). Financial factors in economic fluctuations. Working Paper Series 1192, European Central Bank. 
Christiano, L. J., Eichenbaum, M., and Evans, C. L. (2005). Nominal rigidities and the dynamic effects of a shock to monetary policy. Journal of political Economy, 113(1):1-45.

Cohen-Cole, E. and Martinez-Garcia, E. (2011). The balance sheet channel. In Alfaro, R., editor, Financial Stability, Monetary Policy, and Central Banking, volume 15 of Central Banking, Analysis, and Economic Policies Book Series, chapter 9, pages 255-297. Central Bank of Chile.

Corsetti, G., Kuester, K., Meier, A., and Müller, G. (2013). Sovereign risk, fiscal policy, and macroeconomic stability. Economic Journal, 123.

Dell'Ariccia, G., Ferreira, C., Jenkinson, N., Laeven, L., Martin, A., Minoiu, C., and Popov, A. (2018). Managing the Sovereign-Bank Nexus. IMF Departmental Papers / Policy Papers 18/16, International Monetary Fund.

DeWalque, G., Pierrard, O., and Rouabah, A. (2010). Financial (in)stability, supervision and liquidity injections: A dynamic general equilibrium approach. Economic Journal, 120(549):1234-1261.

Dib, A. (2010). Capital requirement and financial frictions in banking: Macroeconomic implications. Technical report.

Fernández-Villaverde, J. and Rubio-Ramírez, J. F. (2009). A baseline dsge model. University of Pennsylvania (October). Robert E. Hall, 229.

Gerali, A., Neri, S., Sessa, L., and Signoretti, F. M. (2010). Credit and banking in a dsge model of the euro area. Journal of Money, Credit and Banking, 42(s1):107-141.

Gertler, M. and Karadi, P. (2011). A model of unconventional monetary policy. Journal of Monetary Economics, 58(1):17-34.

Guerrieri, L., Iacoviello, M., and Minetti, R. (2012). Banks, sovereign debt, and the international transmission of business cycles. NBER International Seminar on Macroeconomics, 9(1):181 213.

Hartwig Lojsch, D., Rodríguez-Vives, M., and Slavík, M. (2011). The size and composition of governement debt in the euro area. Occasional Paper Series 132, The European Central Bank.

Iacoviello, M. (2005). House prices, borrowing constraints, and monetary policy in the business cycle. American Economic Review, 95(3):739-764.

Jimenez, G., Ongena, S., Peydro, J.-L., and Saurina, J. (2012). Credit supply and monetary policy: Identifying the bank balance-sheet channel with loan applications. American Economic Review, 102(5):2301-26. 
Kaminsky, G. L., Reinhart, C. M., and Vegh, C. A. (2003). The unholy trinity of financial contagion. Journal of Economic Perspectives, 17(4):51-74.

Kiyotaki, N. and Moore, J. (1997). Credit cycles. Journal of Political Economy, 105(2):211-48.

Kollmann, R. (2012). Global banks, financial shocks and international business cycles: Evidence from estimated models. Technical report.

Kollmann, R., Enders, Z., and Muller, G. J. (2011). Global banking and international business cycles. European Economic Review, 55(3):407-426.

Lubik, T. (2003). Investment spending,equilibrium indeterminacy and the interactions of monetary and fiscal policy. Economics Working Paper Archive 490, The Johns Hopkins University,Department of Economics.

Rousseas, S. (1985). A markup theory of bank loan rates. Journal of Post Keynesian Economics, $8(1): 135-144$.

Smets, F. and Wouters, R. (2003). An estimated dynamic stochastic general equilibrium model of the euro area. Journal of the European Economic Association, 1(5):1123-1175.

Smets, F. and Wouters, R. (2007). Shocks and frictions in us business cycles: A bayesian dsge approach. American economic review, 97(3):586-606.

Suh, H. (2012). Dichotomy between macroprudential policy and monetary policy on credit and inflation. Technical report.

Svensson, L. E. (2012). Comment on michael woodford, "inflation targeting and financial stability". sveriges riksbank economic review, (1):33-39.

Woodford, M. (2012). Inflation targeting and financial stability. NBER Working Papers 17967, National Bureau of Economic Research, Inc. 


\section{Appendix}

\section{Entrepreneurs first order condition:}

Entrepreneur maximization program is:

$$
\max _{\bar{\omega}_{t+1} \varrho \varrho_{t}}\left(1-\Gamma_{t}\left(\bar{\omega}_{t+1}\right)\right) R_{t+1}^{E} \varrho_{t} N W_{t}
$$

subject to:

$$
\left[\Gamma\left(\bar{\omega}_{t+1}\right)-\mu G\left(\bar{\omega}_{t+1}\right)\right] \varrho_{t} \frac{R_{t+1}^{E}}{R_{t}^{I}}=\varrho_{t}-1
$$

The Lagrangian is:

$$
\begin{aligned}
\mathcal{L}_{t+1}=\frac{1}{\pi_{t+1}}\left(1-\Gamma_{t}\left(\bar{\omega}_{t+1}\right)\right) R_{t+1}^{E} \varrho_{t} N W_{t}+ & \\
& \zeta_{t+1}\left(\left[\Gamma\left(\bar{\omega}_{t+1}\right)-\mu G\left(\bar{\omega}_{t+1}\right)\right] \varrho_{t} \frac{R_{t+1}^{E}}{R_{t}^{I}}-\left(\varrho_{t}-1\right)\right)
\end{aligned}
$$

where $\zeta_{t+1}$ is the associated Lagrange coefficient to lender banks' zero profit condition. The first order conditions are:

$$
\begin{gathered}
\varrho_{t}: \frac{1}{\pi_{t+1}}\left(1-\Gamma_{t}\left(\bar{\omega}_{t+1}\right)\right) R_{t+1}^{E} N W_{t}+\zeta_{t+1}\left(\left[\Gamma_{t}\left(\bar{\omega}_{t+1}\right)-\mu G_{t}\left(\bar{\omega}_{t+1}\right)\right] \frac{R_{t+1}^{E}}{R_{t}^{I}}-1\right)=0 \\
\bar{\omega}_{t+1}: \frac{-\Gamma_{t}^{\prime}\left(\bar{\omega}_{t+1}\right)}{\pi_{t+1}} R_{t+1}^{E} \varrho_{t} N W_{t}+\zeta_{t+1}\left(\left[\Gamma_{t}^{\prime}\left(\bar{\omega}_{t+1}\right)-\mu G_{t}^{\prime}\left(\bar{\omega}_{t+1}\right)\right] \varrho_{t} \frac{R_{t+1}^{E}}{R_{t}^{I}}\right)=0
\end{gathered}
$$

where

$$
\begin{aligned}
1-\Gamma_{t}^{\prime}\left(\bar{\omega}_{t+1}\right) & =F\left(\bar{\omega}_{t+1}\right) \\
\Gamma_{t}^{\prime}\left(\bar{\omega}_{t+1}\right)-\mu G_{t}^{\prime}\left(\bar{\omega}_{t+1}\right) & =1-F\left(\bar{\omega}_{t+1}\right)-\mu \bar{\omega}_{t+1} F\left(\bar{\omega}_{t+1}\right)
\end{aligned}
$$

simplifying the first order conditions gives:

$$
\begin{aligned}
& \left(1-\Gamma_{t}\left(\bar{\omega}_{t+1}\right)\right)+ \\
& \frac{\Gamma_{t}^{\prime}\left(\bar{\omega}_{t+1}\right)}{\left(\left[\Gamma_{t}^{\prime}\left(\bar{\omega}_{t+1}\right)-\mu G_{t}^{\prime}\left(\bar{\omega}_{t+1}\right)\right] \frac{R_{t+1}^{E}}{R_{t}^{I}}\right)}\left(\left[\Gamma_{t}\left(\bar{\omega}_{t+1}\right)-\mu G_{t}\left(\bar{\omega}_{t+1}\right)\right] \frac{R_{t+1}^{E}}{R_{t}^{I}}-1\right)=0
\end{aligned}
$$




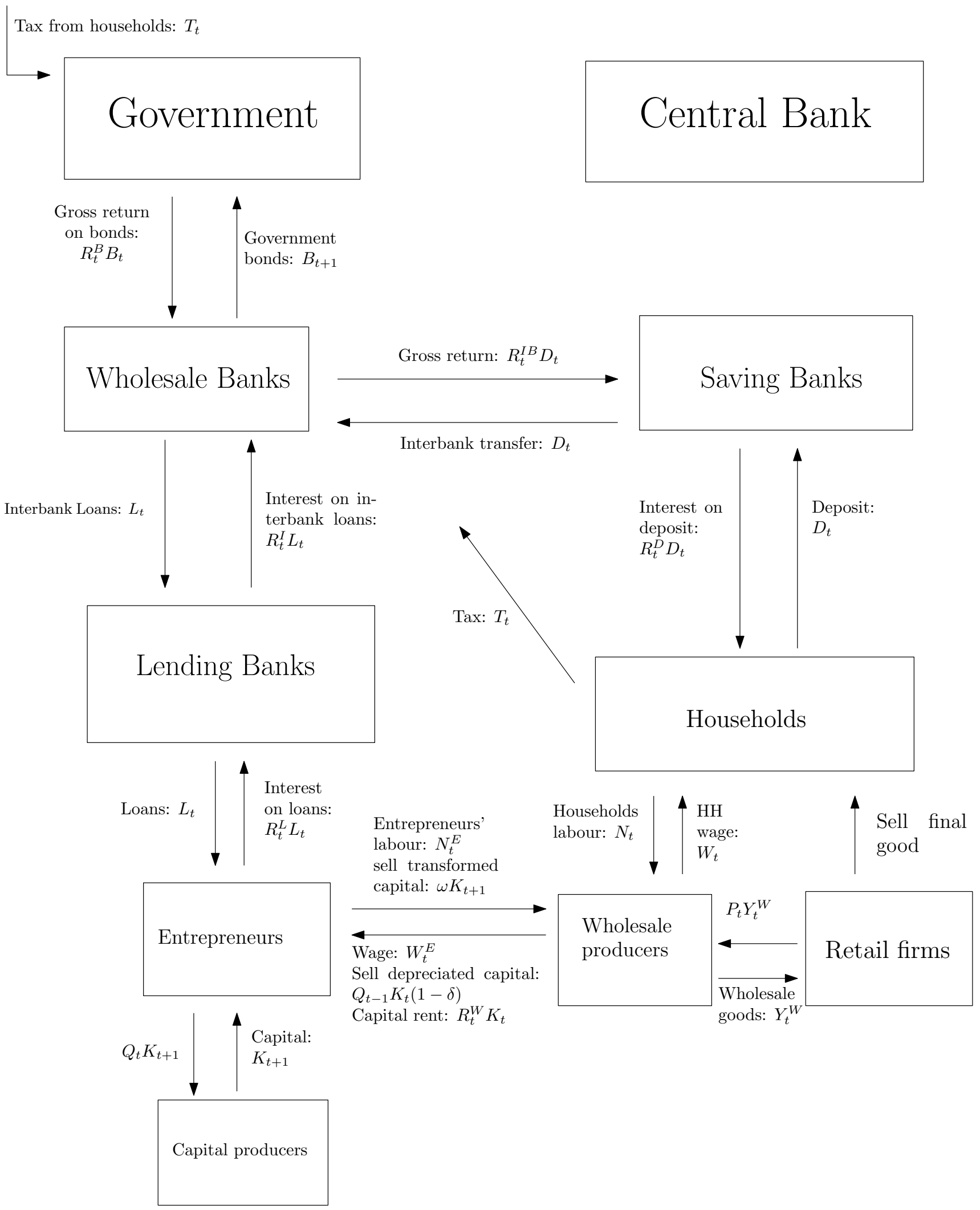




\begin{tabular}{cll}
\hline Parameter & Symbole for & Value \\
\hline$\beta$ & Discount factor & 0.99 \\
$\sigma$ & Households' risk aversion parameter & 0.5 \\
$\phi$ & Household utility elasticity for work & 0.1 \\
$\alpha$ & Share of households' labour & 0.7 \\
$\rho$ & Share of entrepreneur's labour & 0.01 \\
$\delta$ & Capital depreciation rate & 0.025 \\
$\chi$ & Coefficient of adjustment cost for investment & 600 \\
$\alpha^{p}$ & Nominal rigidities & 0.85 \\
$\theta$ & Elasticity in the CES production function & 6 \\
$\varepsilon^{D}$ & Deposit banks monopoly power & 50 \\
$\kappa^{D}$ & Coefficient of adjustment cost for deposit interest rate & 2.4 \\
$\tau$ & Tax rate & 0.215 \\
$\mu$ & Entrepreneurs' monitoring cost & 0.21 \\
$\sigma^{\omega}$ & Standard deviation for log-normal distribution of $\omega$ & 0.082 \\
$\lambda_{W}$ & Capital-to-Asset ratio requirement & 0.08 \\
$\delta^{b}$ & Risk weight for government bonds & 0.2 \\
$\bar{\delta}^{l}$ & Risk weight for interbank loans & 0.5 \\
$\eta^{b}$ & Power in risk weighing asset framework for bonds & 45.27 \\
$\eta^{l}$ & Power in risk weighing asset framework for loans & 17.5 \\
\hline
\end{tabular}

Table 1: Calibrated parameters

\begin{tabular}{|c|c|c|}
\hline Variables & Definition & Values \\
\hline \multicolumn{3}{|c|}{ Steady state values } \\
\hline$\pi$ & Inflation & 1 \\
\hline$R^{f}$ & Policy rate & 1.0303 \\
\hline$R^{D}$ & Deposit rate & 1.0101 \\
\hline$\varrho$ & Entrepreneurs' leverage ratio & 2.0282 \\
\hline$R^{E} / R^{I}$ & External risk premium & 1.0202 \\
\hline \multicolumn{3}{|c|}{ Steady state ratios } \\
\hline$K / Y$ & Capital to GDP ratio & 2.09 \\
\hline$X / Y$ & Investment to GDP ratio & 0.0524 \\
\hline$\left(C+C^{E}\right) / Y$ & Consumption to GDP & 0.7298 \\
\hline$G / Y$ & Public Spending to GDP & 0.1728 \\
\hline$K^{W B} / Y$ & Bank Capital to GDP & 0.1330 \\
\hline$L / Y$ & Loan to GDP ratio & 1.1480 \\
\hline$D / Y$ & Deposit to GDP ratio & 1.6153 \\
\hline$B / Y$ & Debt to GDP ratio & 0.4432 \\
\hline
\end{tabular}

Table 2: Steady States ratios 
Portugal CDS vs ROA

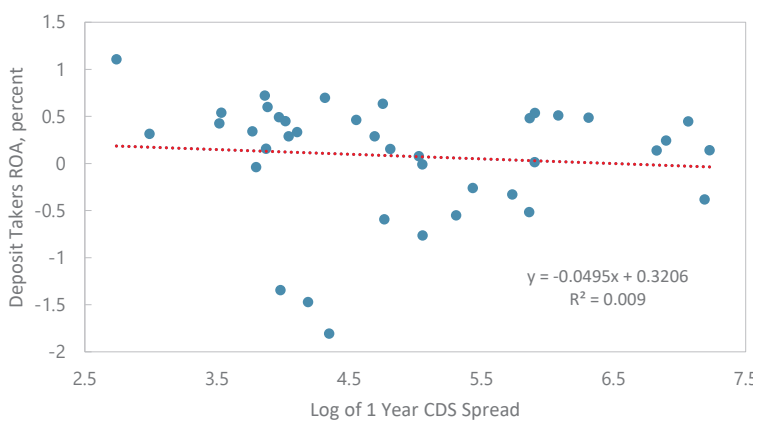

Italy CDS vs ROA

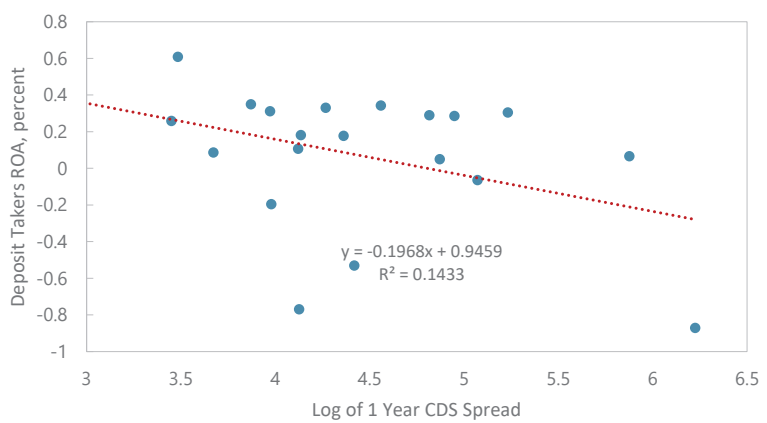

Spain CDS vs ROA

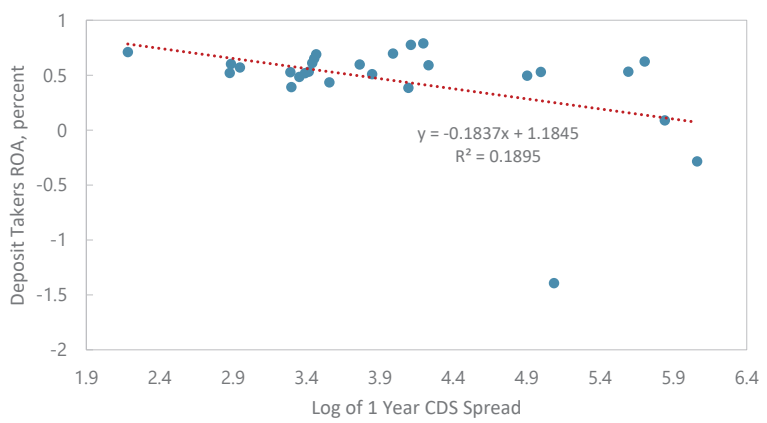

Ireland CDS vs ROA

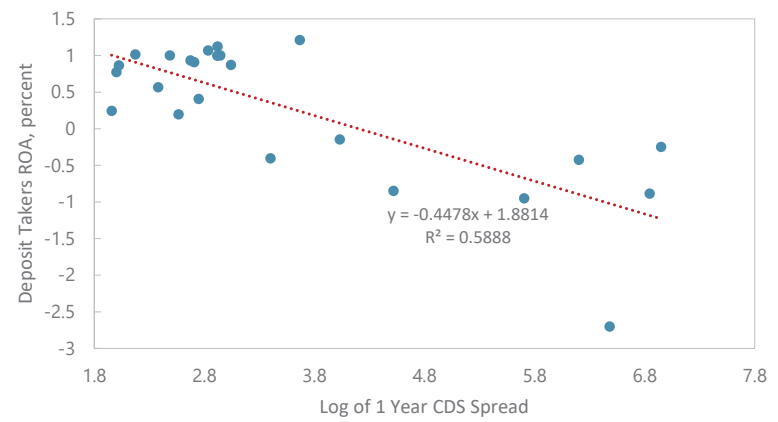

Greece CDS vs ROA

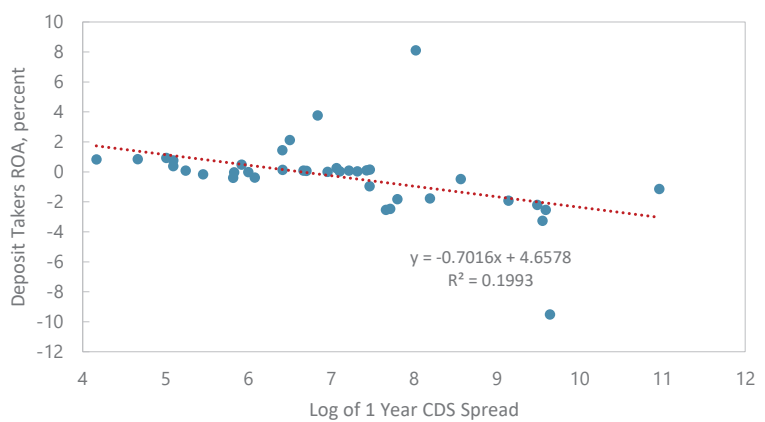

Overall CDS vs ROA

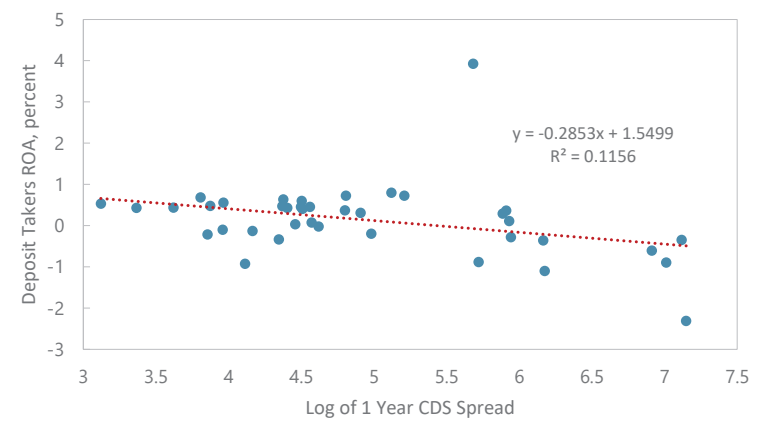


Figure 3: Monetary shock: full model (black line) and model without Rotemberg adjustment cost function (blue dashed line)
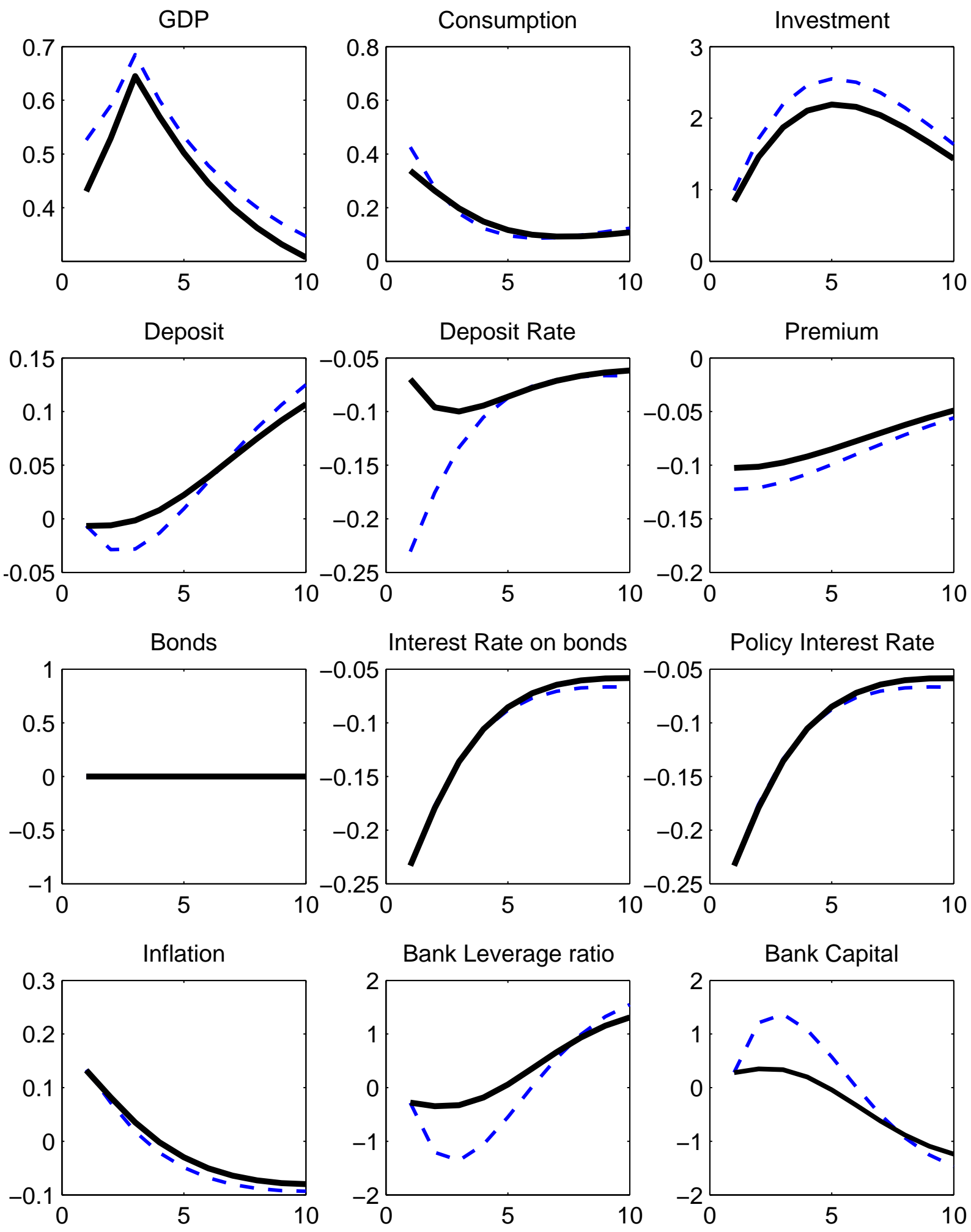
Figure 4: Monetary shock: full model (black line) and model without wholesale banks' under-capitalization cost function (blue dashed line))
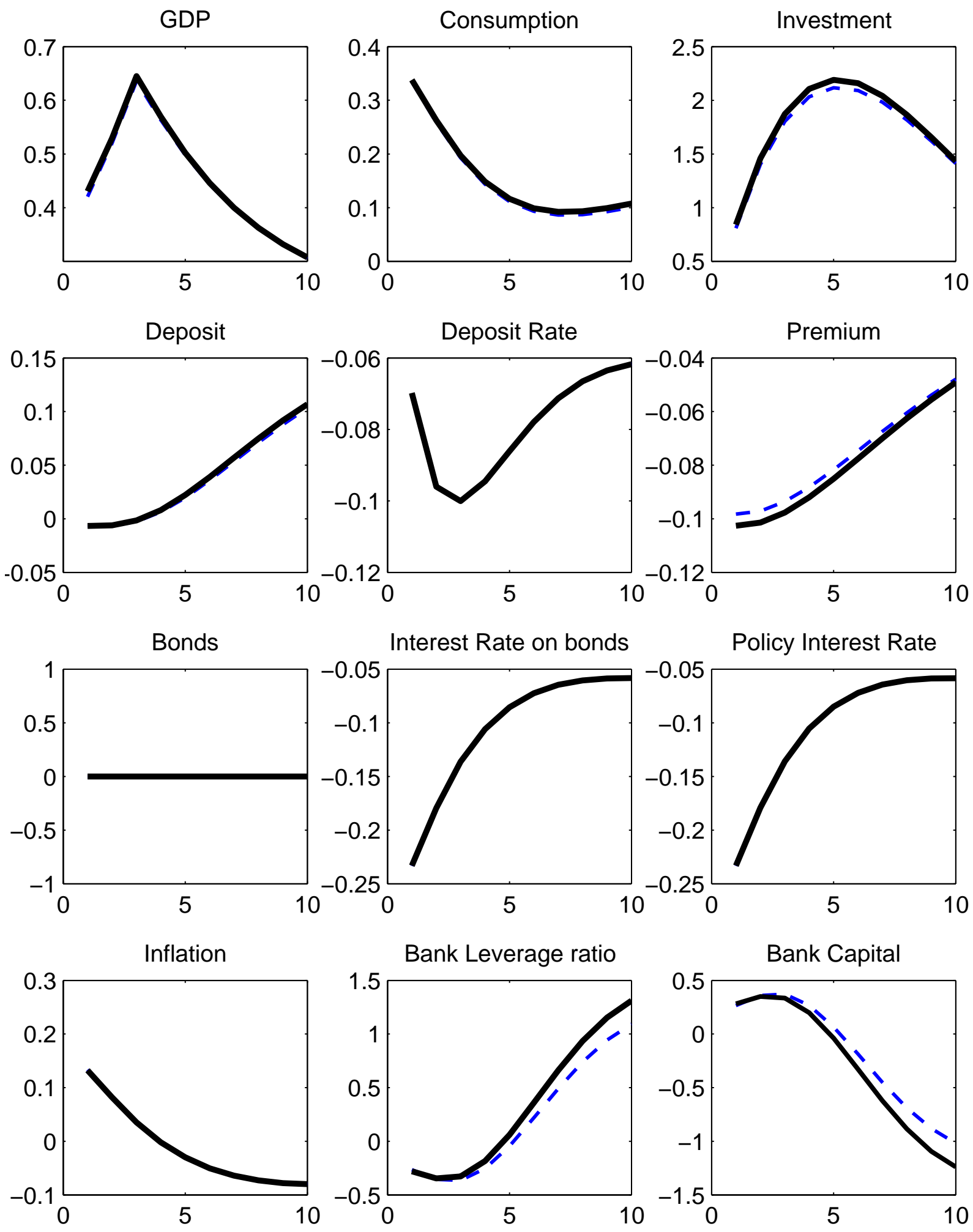
Figure 5: Sovereign shock: full model (black line) and model without the financial accelerator (blue dashed line)
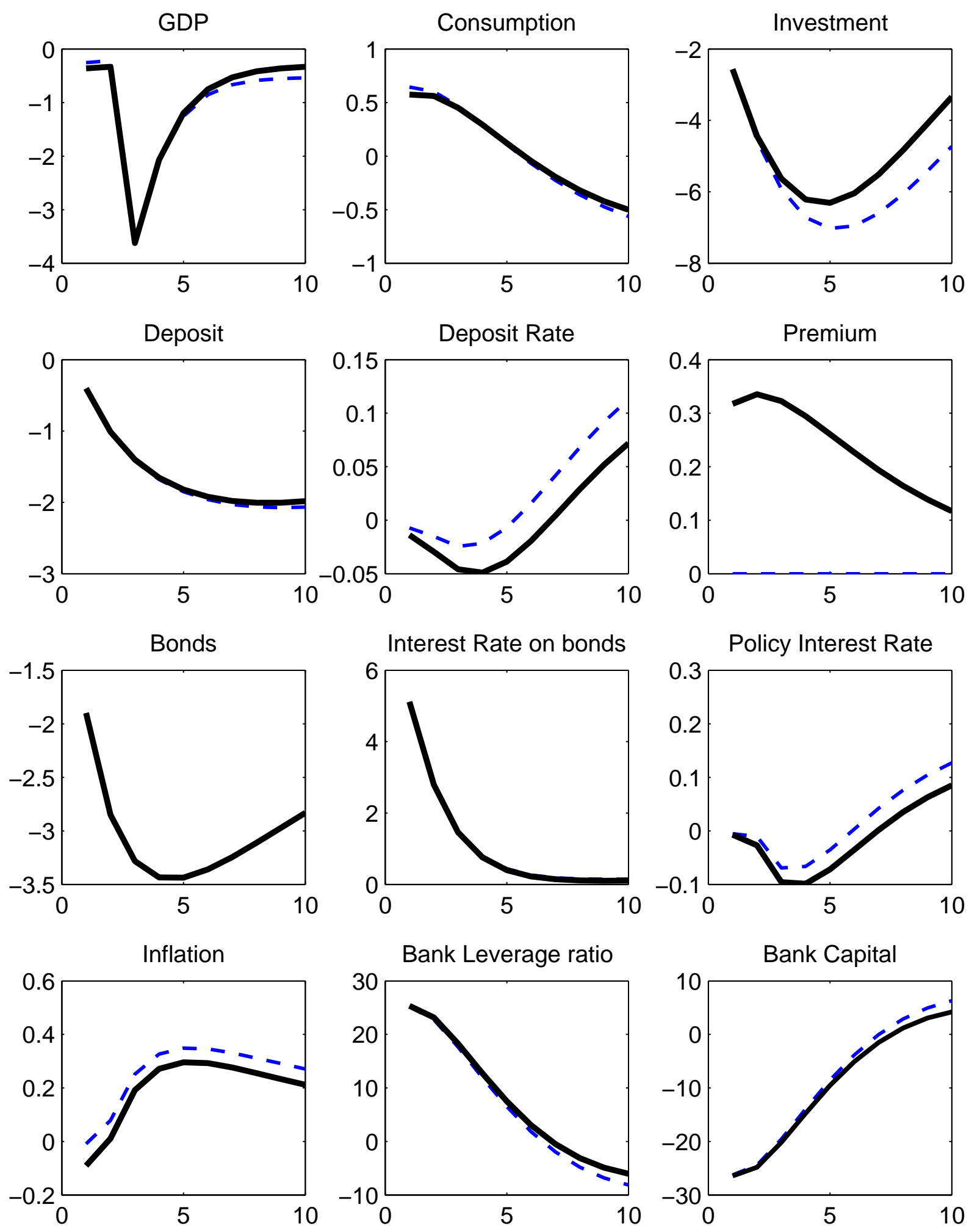
Figure 6: Sovereign default shock shock: full model (black line) and model without wholesale banks' under-capitalization cost function (blue dashed line))
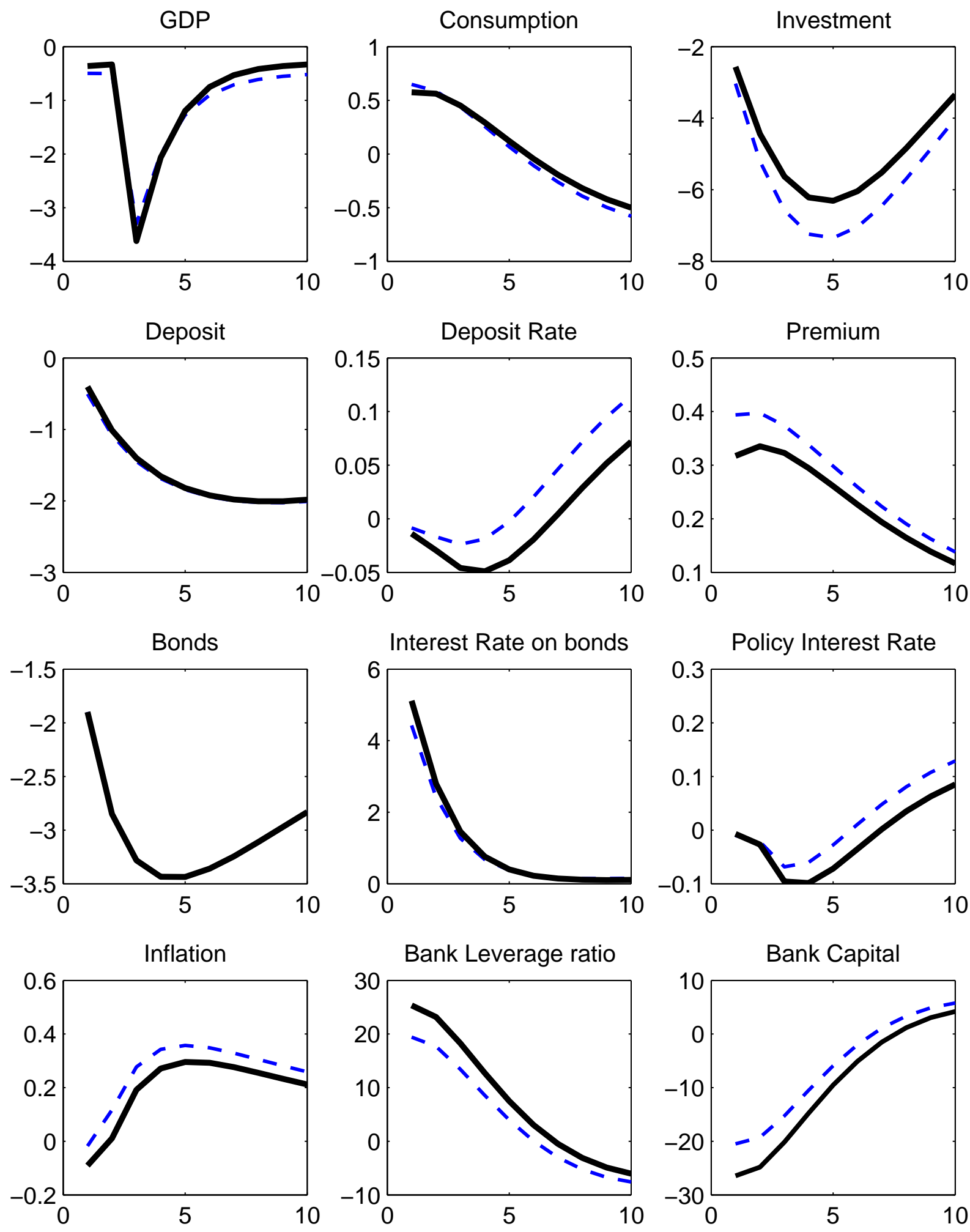
Figure 7: Sovereign default shock shock: full model, i.e. Basel II and III (black line) and model without time-varying risk weights, i.e. Basel I framework (blue dashed line))
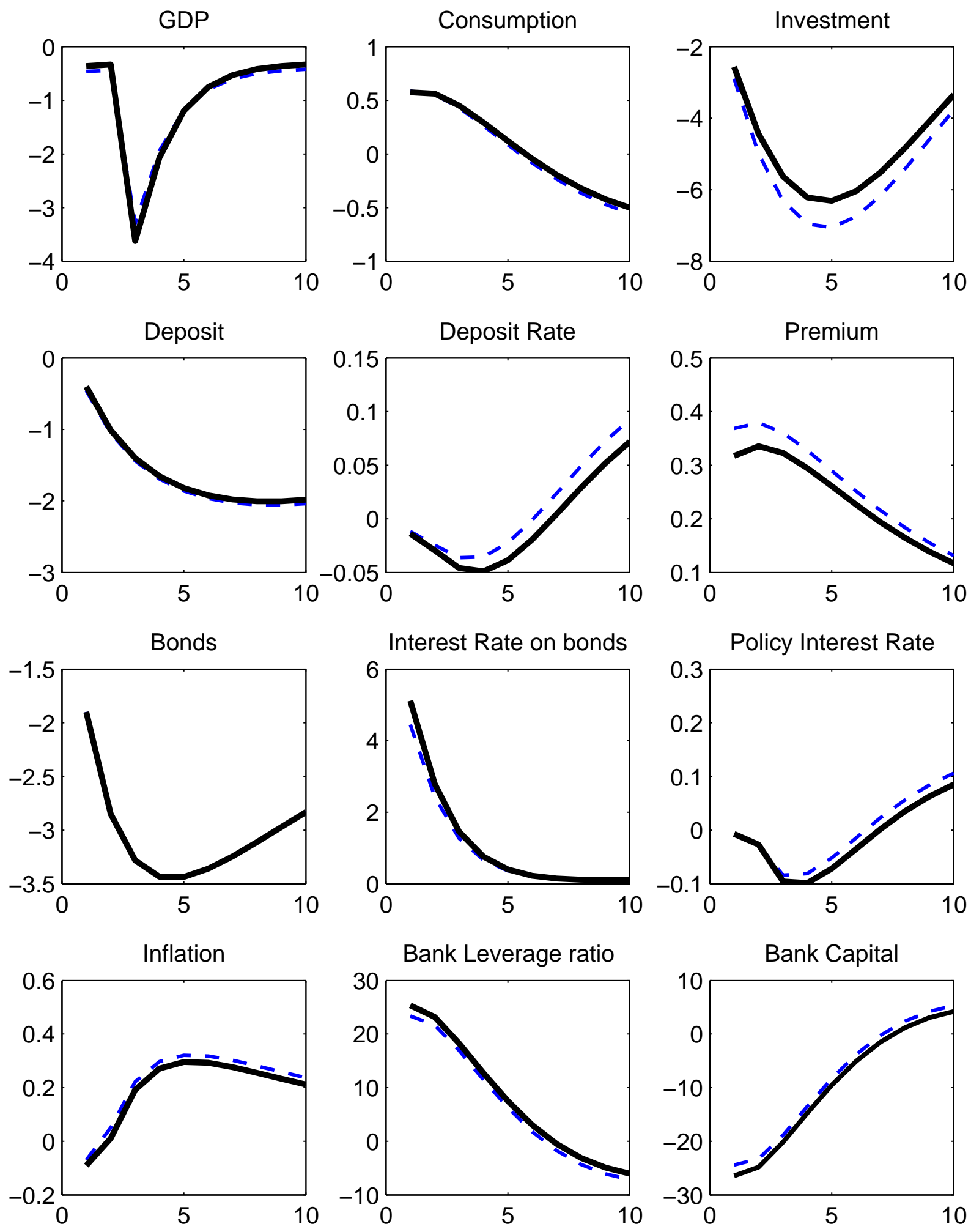